Relations industrielles

Industrial Relations

\title{
TUC: The Growth of a Pressure Group 1868-1976, by Ross M. Martin, Oxford, Oxford University Press, 1980, 394 pp.
}

\section{Jacques Bélanger}

Volume 36, numéro 4, 1981

URI : https://id.erudit.org/iderudit/029223ar

DOI : https://doi.org/10.7202/029223ar

Aller au sommaire du numéro

Éditeur(s)

Département des relations industrielles de l'Université Laval

ISSN

0034-379X (imprimé)

1703-8138 (numérique)

Découvrir la revue

Citer ce compte rendu

Bélanger, J. (1981). Compte rendu de [TUC: The Growth of a Pressure Group 1868-1976, by Ross M. Martin, Oxford, Oxford University Press, 1980, 394 pp.] Relations industrielles / Industrial Relations, 36(4), 956-958.

https://doi.org/10.7202/029223ar

Tous droits réservés @ C Département des relations industrielles de l'Université Laval, 1981
Ce document est protégé par la loi sur le droit d'auteur. L'utilisation des services d'Érudit (y compris la reproduction) est assujettie à sa politique d'utilisation que vous pouvez consulter en ligne.

https://apropos.erudit.org/fr/usagers/politique-dutilisation/ 
the early twenties, the ACLU now stood, during the early New Deal years, in opposition to most liberals and democratic socialists, and was firmly in the camp of those who sympathized with the Soviet Union and the American Communist Party. In fact, it was not until almost the end of the thirties, after the Stalin purge trials and the Nazi-Soviet Pact, that the ACLU severed its close connections with the revolutionary left. Here again, on these events, there are better accounts than Daniel's, including Peggy Lamson's biography, Roger Baldwin (Houghton Mifflin, 1976), and Charles L. Markman, The Noblest Cry: A History of the American Civil Liberties Union (St. Martin's Press, 1965).

Indeed, one wonders why this book was published. There is enough well-researched material in it for an article-length study of the ACLU and the New Deal's labour policies to 1935 (although this would shed little new light on the subject, but mainly fill in a number of details). But there is not enough on American liberals and liberal thought in the thirties in this short book to justify the subtitle, and this subject has in any case already been well analyzed by Warren. Moreover, anyone in research of an analysis of New Deal labour policy and the Wagner Act is better served by Irving Bernstein, New Deal Collective Bargaining Policy (University of California Press, 1950), and James A. Gross, The Making of the National Labor Relations Board (State University of New York Press, 1974).

Even Daniel's thesis, that it was mainly the shock of the depression which turned some liberals leftwards, away from gradual reform, is suspect. As Warren points out, the twenties too were a time of disillusionment for liberal reformers, as a result of their loss of influence over government policy. Their all-too-apparent impotence in the era of Calvin Coolidge, Ronald Reagan's favorite president, prepared some of them for leftwing or pro-Communist activism in the thirties. In 1928, before the crash, Roger Baldwin had already declared in his book Liberty under the Soviets (Vanguard Press, 1928) that individual rights could not exist until classes based on economic exploitation were destroyed. It was just a short step from here to his pro-Communist position of the thirties.

To sum up, Daniel's book is not an entirely satisfactory guide to any of the subjects which it undertakes to discuss.

Hugh TUCK

Memorial University

of Newfoundland

TUC: The Growth of a Pressure Group 1868-1976, by Ross M. Martin, Oxford, Oxford University Press, 1980, 394 pp.

Ce volume est le fruit d'une longue recherche de Ross Martin, professeur de science politique en Australie, sur l'histoire du Trades Union Congress, la plus ancienne des centrales syndicales nationales. L'étude porte sur le processus par lequel ce regroupement syndical, modeste lors de sa fondation en 1868 , est devenu l'un des principaux groupes de pression dans le régime politique britannique.

L'attention porte sur l'évolution de l'autorité du TUC comme intermédiaire entre le gouvernement et les syndicats affiliés. Afin d'établir sa représentativité comme groupe de pression, le TUC doit acquérir une certaine autorité par rapport au Pouvoir politique (“'external authority") et, pour ce faire, refléter un courant d'opinion significatif à l'intérieur du mouvement syndical ("internal authority"').

Outre le caractère modeste de l'action politique du TUC au cours de ses premières années d'existence, c'est cette difficulté à s'imposer comme le principal porte-parole du mouvement syndical qui soulève d'abord l'intérêt du lecteur. Bien sûr, les tensions qui se manifestent au tournant du siècle entre le courant Lib-Lab (dominant chez les leaders syndicaux) et les Socialistes sont très significatives. Toutefois, l'argument fondamental des chapitre 4 (1890-1905) et 5 (1906-1914) porte sur «l'autorité interne» de la centrale syndicale. Et paradoxalement, le challenge 
venait justement d'organisations à la formation desquelles le TUC avait grandement contribué. Ainsi, l'auteur soutient que "the TUC's raison d'être had substantially disappeared with the Labour party's emergence as the labour movement's specialized political organ, and with the creation of the General Federation of Trade Unions as its specialized industrial organ" (p. 113). Cela mettait en cause l'existence même du TUC, celui-ci étant devenu "the sick man of the labour movement" (p. 126).

L'auteur situe le tournant dans les années 1920 , alors que la centrale syndicale manifeste une plus grande indépendance par rapport au Parti travailliste. Il s'est alors opéré une réforme structurelle à l'intérieur de celle-ci avec la création du Conseil général, un certain élargissement des pouvoirs et un renforcement de l'appareil administratif sous le leadership de Walter Citrine.

Dans un chapitre intitulé "Profit from Disaster 1927-1937", Martin soutient que le TUC a établi sa préséance sur le Parti travailliste durant cette période marquée par la crise économique et aussi la crise au sein du Parti (1931). À partir de là, "the TUC tended to be the dominant partner”' (p. 229). Et c'est avec la deuxième guerre mondiale, alors que le gouvernement a développé des rapports soutenus avec le TUC, que ce dernier aurait établi son hégémonie sur le courant industriel du mouvement ouvrier. Ainsi, à partir de 1940, "both unions and government had accorded the TUC an enlarged political authority that was to prove the pattern of the future" ( $p$. 244).

Le chapitre couvrant la longue période de 1940 au dernier gouvernement Wilson (1976), au cours de laquelle le TUC aurait simplement consolidé sa position, ajoute assez peu à l'argumentation de l'auteur. Par implication, il faudrait donc en retenir que la contribution des gouvernements travaillistes à l'établissement du TUC comme groupe de pression aurait été très modeste. Bien plus, l'auteur soutient que dans l'ensemble, l'élection d'un gouvernement travailliste ne produit pas d'effet positif en ce qui a trait à la qualité des rapports gouvernement-centrale et à l'efficacité du TUC comme groupe de pression. On aurait toutefois pu s'attendre à ce qu'une telle recherche nous apprenne davantage sur le processus par lequel la centrale exerce son influence sur le Parti et sur la façon par laquelle cette même influence semble lui échapper lorsque ce même Parti devient gouvernement.

Mais que doit-on retenir sur le succès du TUC comme groupe de pression, sur son efficacité? À cet égard, l'auteur s'intéresse davantage à sa possibilité d'accès à la prise de décision gouvernementale plutôt qu'à sa capacité relative d'influencer le gouvernement dans le sens de ses politiques. L'auteur argumente à l'effet que l'accès à la gouverne politique est ce que tout groupe de pression recherche avant tout: "Without access, aspiring pressure groups have died, or have been severely constrained... It is virtually sine qua non. As such, it takes priority over policy achievements" (p. 15). On notera aussi qu'une telle orientation vers l'étude de la procédure, ou de la façon dont se prennent les décisions, piutôt que vers celle du contenu ou de la substance de celles-ci est caractéristique de l'approche pluraliste.

Or, si son récit de l'histoire du TUC lui permet effectivement de conclure à une expansion «colossale» du nombre et de la diversité des modes d'accès au gouvernement ( $p$. 337), l'auteur est avec raison beaucoup plus réservé dans son bilan de l'efficacité de la centrale syndicale à influencer le gouvernement dans le sens de ses intérêts. Et le professeur Martin ne manque pas de souligner l'évidence: "Persuading government officeholders to listen is one thing; persuading them to accept what they hear is obviously a quite different matter' (p. 338). S'il avait mis plus d'emphase sur la question des réalisations politiques du TUC, le chercheur aurait été confronté à la contrepartie de la tendance au développement des organisations centrales à laquelle il réfère en conclusion. Dans le cas du syndicalisme britannique, cette contrepartie se manifeste non seulement par l'autonomie des syndicats nationaux mais aussi par la liberté relative d'action des organisations syn- 
dicales sur les lieux de travail, ce qui affaiblit considérablement la position du TUC dans ses rapports avec l'État.

S'il y a lieu d'émettre certaines réserves sur le trop peu d'attention accordée à certains aspects de la question, et aussi de noter que le cadre d'analyse un peu rigide tend parfois à rendre la discussion répétitive, il faut surtout retenir qu'il s'agit dans l'ensemble d'un ouvrage intéressant sur un sujet fascinant. Le professeur Ross Martin nous offre une recherche d'une très grande qualité sur le plan académique.

\section{Jacques BÉLANGER}

Université Laval

Labour Studies Research Bulletin, Labour Studies Resource Centre, Department of Political Science, Carleton University, 1981, $32 \mathrm{pp}$.

One of the most striking phenomena over the last few years has been the appearance of several research "bulletins", in such specialized fields as urban studies, leisure activities and labour studies. The Labour Studies Research Bulletin of Carleton University is the most recent of this trend, which attempts to find a form of expression between the ephemeral "newsletter" and the fullblown "scientific journal". It is the third of its kind in the labour field, having been preceeded by the CCLH's Bulletin on labour history and the RCHTQ's Bulletin RCHTQ on interdisciplinary labour research. Each of its predecessors found itself compelled to become quite elaborate as time went on, and this may also be the fate of the present publication. The former was finally swallowed up by the journal Labour/Le travailleur, cutting English-speaking readers off from such a medium, while the latter has maintained its presence among its Francophone readership. The logical question is whether the new bulletin is simply an attempt to fill the gap left by the CCLH's disappearance from the field or the result of completely independent factors.

In its origins, the second seems to be the answer. Founded by political scientists, it indicates the first concerted effort of that disci- pline to enter the field of labour research. The editors are quick to indicate, however, their intention to avoid monopoly and promote an interdisciplinary approach. In this respect, the Labour Studies Research Bulletin appears have much the same mission as its only competitor, the Bulletin RCHTQ. Another similarity is the preoccupation with purely labour studies, with a leaning toward the understanding and promotion of labour's case. The editorial statement is loud and clear as is the subsequent note of the Editorial Committee: "Against the background of mainstream industrial relations research, it is hoped that this publication will facilitate endeavours by labour researchers to produce alternative, progressive studies not only of but for workers and their unions". (Italics mine, p. 2) The feature essay, by Research Officer Geoff Bickerton of the C.U.P.W., picks up this same theme and strikes out at I.R. specialists, criticizing present orientations and suggesting new ones.

The sweeping generalizations of the Editorial Committee and its feature writer pose a problem for the future orientation of this new bulletin. Is organized labour looking for a vehicule to express its views? How will contributions of researchers, not entirely favourable to labour, be treated? Will there be a distinction between research and more polemical material published? Such questions indicate important problems to be resolved.

As regards other aspects of present content, the accent placed on abstracts ( 21 pages of a total of 32) seems exaggerated. A shorter integrated review essay would probably be better. Otherwise the material presented in this first issue is quite useful.

As a concluding comment, certain similarities between this bulletin and that of the RCHTQ suggest the possibility of formal or informal links between the two in their mutual interest. Good luck to the new team in their challenging task!

James THWAITES

Université Laval 